\title{
ШЕКСПИРОСФЕРА
}

DOI: $10.17805 / \mathrm{ggz} .2018 .6 .8$

\section{О вариативности переводов ранних комедий Шекспира: некоторые замечания"}

B. С. Макаров

Православный Свято-Тихоновский гуманитарный университет, 2. Москва

В статье представлены некоторые особенности анализа корпуса русских переводов четырех ранних комедий У. Шекспира на основе посегментного сопоставления их с помощью платформы Version Variation Visualization. Хотя высказанная в прошлых работах идея о влиянии жанра на структуру корпуса пока не нашла подтверждения, по результатам двухлетнего проекта оказалось возможным описать характерную структуру корпуса переводов шекспировских пьес по их вариативности и проанализировать динамику изменения этого показателя.

Ключевые слова: У. Шекспир; ранние комедии; перевод; Version Variation Visualization; вариативность; динамика вариативности

\section{Notes on Variation in Translations of Shakespeare's Early Comedies} V. S. Makarov

\section{St. Tikhon's Orthodox University, Moscow}

The article deals with specific strategies of analysing the corpora of Russian translations of four early comedies by William Shakespeare as the translations appear in the course of speech-by-speech comparison by means of the Version Variation Visualization platform (VVV). Although the hypothesis of genre-induced variation has so far remained unproved, the two-year project of implementing a Russian instalment of VVV with corpora of Shakespeare's plays has allowed us to examine and describe the structure of a corpus and variation within it, as well as analyse the dynamics of such variation.

* Статья подготовлена в рамках проекта «Разработка и внедрение в открытом доступе онлайн-программы сравнительного тезаурусного анализа русских переводов произведений У. Шекспира», осуществляемого при поддержке РФФИ (проект № 17-04-12038в).

The paper was prepared within the framework of the project "Development and Launching of Open Access Online Digital Tools for Comparative Thesaurus Analysis of Russian Translations of W. Shakespeare's Works" with support from the Russian Foundation for Basic Research (project no. 17-04-12038в). 
Keywords: W. Shakespeare; early comedies; translation; Version Variation Visualization; variation; variation dynamics

\section{ВВЕДЕНИЕ}

Ранние шекспировские комедии - «Комедия ошибок», «Два веронца», «Бесплодные усилия любви», «Укрощение строптивой» - написаны в первой половине 1590-х гг. и вместе с хрониками составляют важный этап в формировании всего последующего шекспировского канона. В них наиболее заметны неанглийский колорит и сильное влияние античной и современной Шекспиру европейской драматической традиции — от Теренция до комедии дель арте.

Как неоднократно отмечали исследователи, велика в них и роль искусства риторики. Линн Магнуссон считает ее самым важным источником для понимания шекспировской комедии: «Основным языковым ресурсом шекспировских комедий и источником обсуждаемых в них языковых идей является искусство риторики» (“A chief resource for the language of Shakespeare's comedies and a source of the ideas about language debated in them is the art of rhetoric" (Magnusson, 2001: 156)). Риторика, как это свойственно ренессансной комедии и теории языка, выступает здесь не просто как искусство словесного убеждения, а в целом как стратегия саморепрезентации героя. И античная традиция, и комедия дель арте, и - во многом - практика елизаветинского театра начала 1590-х гг. опиралась на стереотипные амплуа героевмасок, чья речь определяется характером маски (отрывистые реплики «хвастливого воина», выстроенные периоды «педанта», тщетные попытки подражать ему «учителя» и т. д.).

Разумеется, У. Шекспир, двигаясь к более сложной комедии, где герои, по крайней мере главные, не столь значительно определяются узнаваемой маской или вообще ее не имеют, не мог не столкнуться с противоречием, которое хорошо охарактеризовал Кристиан Смидт в работе о т. н. шекспировских «несоответствиях» (“unconformities”). Стереотипизация, к которой, по мнению Смидта, легко приводило влияние комедии дель арте, ограничивала не только психологию героя, но и сам сюжет комедии, зато создавала «эффект сохранения» (“conservation of character"; Smidt, 1986: 9), который позволял строить более четкий сюжет. Постепенный отход от «масочности» с помощью unconformities - несоответствий ожидаемому, когда один герой, как дон Армадо, начинает сочетать в себе черты нескольких масок («хвастливый воин», «лгун-путешественник» и отчасти даже «педант»). Другой пример безымянный путешественник, нанятый в «Укрощении строптивой» изображать Винченцио, о котором Бьонделло говорит «то ли торговец, то ли педант» 
(“a mercatante, or a pedant"; IV, 2). Эта смесь амплуа неизбежно отражается в речи персонажей.

Среди других факторов, определяющих риторику ранних шекспировских комедий - влияние эвфуистической прозы и менее эвфуистических комедий Т. Лили, о котором писал известный шекспировед Т. Болдуин и с которым, тем не менее, не полностью соглашался Э. М. У. Тиллъярд - автор первой монографии о ранних комедиях Шекспира. Он полагал, что влияние Лили было лишь стилистическим (см.: Tillyard, 1965: 23), особенно с учетом свойственной Шекспиру крайней «ассимилятивности» (“immensely assimilative"; ibid: 12).

Наконец, фарсовость ранних комедий многие авторы вслед за Сезаром Барбером объясняют через связь с фольклорными, в том числе античными практиками и ритуалами сообществ (см.: Barber, 2011: 235, 250). Рассуждая о «капризах остроумия» и «маскараде» ранних шекспировских комедий ("folly of wit and masquerade" (ibid: 99), Барбер также отмечал выход Шекспира за рамки предвидимого и легко предсказуемого развития сюжетных событий.

Очевидно, что и внимательный переводчик также должен был бы уделить внимание риторике саморепрезентации героев. К сожалению, рефлексия такого рода, если она и была зафиксирована, то осталась в архивах — за исключением обширной статьи К. И. Чуковского о «Бесплодных усилиях любви» (1960), которая, впрочем, большей частью посвящена оправданию отказа от эквилинеарности и критике предыдущих переводческих традиций. Чуковский ополчается на дореволюционные «глухонемые переводы для глухонемого читателя», упрекая их в том, что они «познавательные» и «кабинетного стиля», а их читатель - «пытливый интеллигент старинных времен», которому Шекспир нужен как «некий литературоведческий памятник», с вступительной статьей и «грудой всевозможных комментариев» (Чуковский, 2012: 648). Одновременно Чуковский атакует и «телеграфную нескладицу» (там же: 651) переводов эквилинеаристов, в данном случае - М. А. Кузмина. Резонно сравнивая стиховую поэтическую дикцию с музыкой и требуя в первую очередь слухового восприятия стиха, Чуковский призывает оставить в стороне «памятники давно угасшего юмора» (это выражение Э. К. Чемберса он повторяет несколько раз; там же: 629-630) и, в сущности, переписать Шекспира ради проникновения в суть его пьесы. Не случайно персонажи, чья речь большей частью состоит из такой «археологической рухляди» (там же: 630) - Натаниэль, Олоферн, Армадо, Мотылек - сильно пострадали в его переводе, из которого, например, исчезла вся сцена с «девятью мужами славы».

В предыдущей работе (Макаров, 2017) мы уже показали, как некоторые установки и стратегии переводчиков отражаются на вариативности их текста, 
выявленной и подсчитанной программной стороной платформы Version Variation Visualization, размещенной на сайте www.shakespearecorpus.ru (о ней см. подробнее: Чизман, 2015). Так, несмотря на добавление в корпус переводов «Бесплодных усилий любви» современной версии Г. М. Кружкова (2017), уникально высокая вариативность перевода К. И. Чуковского $($ Eddy $=1,02)$ осталась неизменной. Чуковский создал текст, одинаково противопоставленный обеим критикуемым им традициям - как дореволюционной стратегии Н. Х. Кетчера, П. И. Вейнберга и др., которую он упрекал в глухонемоте за прозаичность и наивную многословность, так и стратегии экспрессивной эквилинеарности М. А. Кузмина и Ю. Б. Корнеева (а как будет ясно из следующего раздела статьи, к ней следует присовокупить и имя редактора по крайней мере первого из переводов - А. А. Смирнова).

Пополнение корпуса новыми данными показало, что представленное в прошлой статье объяснение верно: язык перевода Чуковского - не предвестие нового этапа шекспировских переводов, а отдельная (к сожалению!) и пока не получившая серьезного продолжения попытка создать «театральный текст» Шекспира.

Два современных перевода ранних шекспировских комедий, исследованных нами в этом году, предлагают несколько иной путь, беря от текста Чуковского его внимание к красивому и современно звучащему стиху, а от «ленинградской» традиции Смирнова, Кузмина и др. - стремление сохранить все сцены и максимально большое число реплик.

Перевод «Бесплодных усилий любви» Г. М. Кружкова, вышедший под заглавием «Пустые хлопоты любви», также демонстрирует значительную вариативность по отношению к остальному корпусу (Eddy=0.94, выше только в переводе Чуковского). И тем не менее переводчику вполне удалось не только соблюсти эквилинеарность, но и сочетать ее с иронией, пусть нередко и слегка модернизирующей текст.

Так, в реплике Бирона "Armado is a most illustrious wight, // A man of fire-new words, fashion's own knight" (I, 1) почти все предыдущие переводчики, очевидно, шли от выражения «рыцарь моды» - оно присутствует у П. А. Каншина, П. И. Вейнберга, М. А. Кузмина, Ю. Б. Корнеева, К. И. Чуковского и С. А. Крынского, и в слегка модифицированном виде - «раб моды» - у Н. Х. Кетчера. В качестве гипотезы можно предположить, что столь легко это выражение может «спуститься на кончик пера» по двум причинам: либо переводчики повторяют друг друга (что маловероятно, учитывая принципиальное отталкивание Смирнова и Кузмина от традиции дореволюционных переводов), либо - что скорее - это выражение приходит на ум переводчику автоматически в силу того, что в языке XIX-XX вв. оно почти клиширова- 
но. На фоне этого поразительно проигрышно смотрится остальные тропы в двустрочной реплике Бирона: “а man of fire-new words", т. е. тот, кто мгновенно создает новые слова, у Кузмина «в речах — огонь», у Крынского «горячи / его словечки, словно из печи», у Вейнберга «жаркий говорун» - везде присутствует семантика «огня» и «жара», и почти нигде (кроме полубессмысленного «человек вновь выкованных словечек» у Каншина) - словотворчества. На фоне этого более сбалансированно выглядит фраза «чеканщик редких слов, разносчик мод» у Кружкова: «разносчик» (пусть и не в том смысле, как «рыцарь») вполне передает зависимость Армадо от моды. Наконец, важно и то, что "most illustrious wight” (досл. «весьма выдающееся существо»), у Кружкова переведено как «просвещения оплот» - выражение для шекспировской Англии, конечно, анахронистическое, но так же, как и в оригинале, явно ироничное. Из предыдущих переводчиков это удалось лишь Кузмину («Армадо - исключительной породы») и Корнееву («В Армадо пропасть блеска и ума»).

При этом вариативность фрагмента как явление прежде всего лексическое (Cheesman et al., 2017: 742) не коррелирует с передачей иронии напрямую. Автоматическое ранжирование величин Eddy демонстрирует, что вариант Кузмина наименее вариативен (0,71, хотя сама величина Eddy показывает, что разброс вариантов довольно велик), в то время как перевод фрагмента Корнеевым и Кружковым занимают соответственно второе и четвертое место по вариативности с показателем Eddy 0,85-0,86). Вне досягаемости здесь Чуковский - главным образом потому, что он меняет синтаксис, выводя «рыцаря мод» в начало реплики, чтобы потом частично потерять в остальных характеристиках.

Если Чуковский удаляет целые группы реплик, освобождая место для расширительного перевода остальных (см. рис. 4 в моей статье: Макаров, 2017: 93), то Кружков, как это ясно из вида “Alignments", избавляется в основном от замедляющих действие реплик (например, "I will tell you sensibly" (Moth; III, 1); “True, true, we are four” (Biron; IV, 3)), как правило, в тех случаях, когда основной диалог идет между другими персонажами.

Другой пример такой работы с ранней шекспировской комедией - перевод «Комедии ошибок» М. Я. Бородицкой, сделанный для нового «петербургского» собрания сочинений драматурга. Сетуя на отсутствие «жизнеспособного перевода» этой ранней шекспировской комедии, Бородицкая противопоставляет существующие «живой и обаятельной» комедии в оригинале. В сущности, это замечание также можно отнести к риторике саморепрезентации героя: тяжеловесность их реплик заставляет увидеть в пьесе несуществующий черновик более поздних шекспировских комедий. 
В этом корпусе, однако, совсем другой состав версий — на три дореволюционные (Кетчер, Вейнберг и Каншин) приходится всего одна ХХ века (Л. С. Некора), которую еще А. А. Смирнов признавал несовершенной: редакторскую работу с переводчиком не удалось провести, так как Л. С. Некора находился в среднеазиатской ссылке, где и скончался. На этом фоне вариативность перевода М. Я. Бородицкой неизбежно высока $(E d d y=0,88)$, и, как и в случае Чуковского, она остается стабильно высокой при изменении состава корпуса (см. рис. ниже).

Корпус «Комедии ошибок» хорошо подтверждает гипотезу Т. Чизмана (Cheesman et al., 2017: 752) о высокой вариативности заключительных двустиший, но происходит это, главным образом, за счет почти полного их игнорирования в дореволюционных переводах. В завершающей второе действие сцене такое двустишие создает комический эффект: в нем за эмоциональной фразой Адрианы, обращенной к Дромио, — “Аy, and let none enter, lest I break your pate" (II, 2; досл. «Да, и никого не пускай, а то я тебе башку пробью»), следует подчеркнуто вежливая реплика Люцианы "Come, come, Antipholus, we dine too late" (досл. «Пойдем, Антифол, пойдем, обед и так запоздал»). Единственный из переводчиков, кроме Бородицкой, кто смог сохранить обе реплики в том же объеме - Л. С. Некора:

\section{АНТИФОЛ СИРАКУЗСКИЙ}

Да, берегись кого-нибудь впустить.

\section{ЛЮЦИАНА}

Пойдемте, брат: успел обед остыть.

(Шекспир, 1949: 37; Шекспир, 1958а: 127) ${ }^{1}$

В первой из строк эмфатическая составляющая полностью утрачена, в то время как у Бородицкой этот контраст сохранен:

\section{АДРИАНА}

И чтоб ни шагу от дверей, тупица!

\section{ЛЮЦИАНА}

Идемте, братец, время подкрепиться.

(Шекспир, 2012: Электронный ресурс)

Обе строки в переводе Бородицкой имеют одинаково высокий показатель вариативности $(\mathrm{Viv}=0,965)$, но для первой строки это один из самых ва-

\footnotetext{
${ }^{1}$ Благодарю Б. Н. Гайдина за привлечение внимания к тому, что в переводе Л. С. Некоры реплика передоверена Антифолу Сиракузскому.
} 
риативных результатов, так как остальные переводчики стремятся сохранить метафору членовредительства (вместо акцента на эмфатической угрозе): «не впускать», «сломаю голову / переломлю башку» и т. д. Во второй строке, наоборот, при том же показателе вариативности, перевод Бородицкой наименее вариативен, так как короток (ср. у Каншина: «Ну, пойдем, Антифол; мы ведь и так будем обедать сегодня слишком поздно»).

Точно соблюдающий смену размеров и рифмовки перевод М. Я. Бородицкой оказывается по вариативности противопоставлен и дореволюционным переводам, и тексту Л. С. Некоры, хотя последнему - в меньшей степени (Eddy 0,88 vs 0,812). Как видно из вышеуказанного примера, высокая вариативность перевода Бородицкой - следствие как более современной лексики в ее переводе, так и более четкого соблюдения эквилинеарности и особенной стратегии отбора слов. Когда пространство строки не беспредельно, а их количество жестко ограничено, приходится выбирать наиболее адекватный вариант, а он подразумевает учет не только лексических, но и стилистических факторов. Это, в сущности, очень близко идее А. А. Смирнова об эквиритмии как регуляторе, упорядочивающем работу переводчика (см.: Каганович, 2018: 142-143).

При дальнейшем расширении корпуса (куда должны войти, например, труднодоступные переводы А.Л. Соколовского) переводческие стратегии должны проявиться еще более явно. Поскольку многие переводчики работали с несколькими шекспировскими текстами разных жанров, что позволяет говорить как об индивидуальных стратегиях подхода к тексту, так и об общих тенденциях передачи языка ранних шекспировских комедий с его поэтичностью и языковой игрой.

\section{СОВПАДАЮЩИЕ ФРАГМЕНТЫ В РУССКИХ ПЕРЕВОДАХ: ОСОБЕННОСТИ РЕДАКТУРЫ?}

Чем менее известна читателю и менее популярна у зрителя шекспировская пьеса, тем более значительную часть корпуса ее переводов будут составлять тексты, выполненные по заказу и под редакцией А. А. Смирнова - для первого (Шекспир, 1936-1950) или второго (Шекспир, 1957-1960) советского полного собрания сочинений Шекспира.

Еще до начала работы над первым из них, Смирнов наиболее жестко сформулировал концептуальную необходимость новых переводов: «Желательно в принципе дать все пьесы в новых переводах. Однако некоторые

\footnotetext{
${ }^{2}$ О единицах Eddy и Viv см.: Cheesman, Roos, 2017: 2-3; Cheesman, Flanagan, Thiel, $2012-$ 2013.
} 
наименее значительные пьесы <..> можно было бы дать в старых переводах, тщательно отредактированных» (цит. по: Каганович, 2018: 124).

Если Смирнов вполне согласен с Чуковским в том, что старые переводчики стремятся «приукрасить Шекспира» и «приладить его к своей собственной поэтике» (Смирнов, 2013: 729), то его обвинения в стилистических промахах звучат гораздо сильнее. Но важны даже не сами эти положения, а уникальная возможность для Смирнова требовать от переводчиков выполнения новой стилистической программы.

Так, по собственному признанию, Смирнов послал 350-400 замечаний Кузмину по его тексту «Двух веронцев» и 60 страниц замечаний по его переводу «Бесплодных усилий любви» (письмо Г. Шпету от 19 августа 1934 г; Густав Шпет ..., 2013: 153), а перед началом работы снабдил Кузмина «всеми пособиями» (письмо Г. Шпету от 27 июня 1933 г.; там же: 26), т. е. комментированным кембриджским изданием под редакцией Дж. Довера Уилсона, словарем шекспировского языка и т. д.

Собирая под крышу издания переводчиков с похожей стратегией работы с шекспировским текстом, ориентированных на точный перевод, особенно в отношении эквилинеарности и эквиритмии, а также передачи исторических деталей, как материальных, так и ментальных, Смирнову - единственному из российских редакторов шекспировских собраний - удалось создать концептуально выверенное издание «русского Шекспира». Именно по этой причине Смирнов отверг в целом нравящийся ему перевод А. Н. Островского: «Меня раньше соблазнял прекрасный язык Островского, но, действительно, очень уж будет выпадать», т. е. не соответствовать общему стилю остальных переводов (письмо Г. Шпету от 15 сентября 1933 г.; там же: 57).

В уже цитировавшейся докладной записке 1956 года А. А. Смирнов тщательно фиксирует состояние дел перед началом работы над второй версией полного собрания сочинений. Чтобы перевод В. В. Левика мог заменить кузминский, необходимо, полагает Смирнов, восстановить в нем все пропуски, вызванные тем, что перевод был сделан для театра. Так как на переводы К. И. Чуковского в этом отношении Смирнов не мог надеяться, он предполагал, что перевод «Комедии ошибок» Л. С. Некоры и «Бесплодных усилий любви» П. И. Вейнберга можно будет подвергнуть «творческой, художественной редактуре» (цит. по: Каганович, 2018: 210-211), которую он предлагал возложить на А. А. Аникста. Новый перевод «Укрощения строптивой» дала П. В. Мелкова под редакцией самого Смирнова.

Обращает на себя внимание, что в трех из четырех случаев Смирнов отказывается от переводов Кузмина, возможно, по идеологическим причинам (хотя для года ХХ съезда КПСС это, мягко говоря, странно) или в рамках сво- 
его «пакта» с московским шекспироведением, которое в редакторском коллективе представлял Аникст ${ }^{3}$.

Тем не менее Кузмин все равно присутствует в более поздних переводах, отредактированных Смирновым, - переводе А. И. Курошевой, сделанном для однотомника 1950 года, и переводе П. В. Мелковой. Изучение вариативности некоторых отрезков (в режиме приближения — zoom in) показало точки почти дословного совпадения, в частности, в переводе «Укрощения строптивой». Взглянем на несколько примеров.

В индукции к пьесе, когда Слаю передают имена тех, кого он называл в пьяном бреду в доме Лорда, все три переводчика называют их одинаково. Ср.:

Как Стивен Слай, да старый Джон Непс-Сало, Да Питер Терф, да Генри Пимпернель.

(пер. М. А. Кузмина; Шекспир, 1937: 13)

Ни Стивен Слай, ни старый Джон Непс-Сало, Ни Питер Терф, ни Хенри Пимпернель...

(пер. А. И. Курошевой; Шекспир, 1950b: 68)

Ни Стивен Слай, ни Старый Джон Непс-Сало, Ни Питер Терф, ни Генри Пимпернел...

(пер. П. В. Мелковой; Шекспир, 1958b: 192)

Разница исключительно графическая: «Пимпернель» Кузмина превращается в «Пимпернела» у Мелковой, а у Курошевой «Генри» становится «Хенри». И если первое, третье и четвертое имя и в оригинале создают необходимый ритм пятистопного ямба и потому в замене не нуждаются, то прозвище (или фамилия) “old John Naps of Greece” переведено как «сало», так как комментаторы рубежа XIX-XX вв. традиционно отмечали почти полную омофонию "Greece" - Греция и "grease" - жир. Очевидно, возможно были бы и другие варианты перевода наподобие «старый сальный Джон» и т. д., но идущие по следам Кузмина Курошева и Мелкова в точности сохраняют форму.

3 Еще одно возможное объяснение - необходимость финансовой поддержки переводчиков. М. А. Кузмин к выходу однотомника 1950 года (Шекспир, 1950а) и второго ПСС (Шекспир, 1957-1960) уже давно скончался, не оставив наследников, и авторский гонорар остался бы в издательстве. 
Еще более очевидный пример - рассказ Бьонделло о том, в каком виде Петруччо приехал на собственную свадьбу (III, 2). Приводим цитаты полностью для удобства сравнения:

\section{- $\quad$ М. А. Кузмин:}

Что Петручио едет сюда в новой шляпе и в старой куртке; на нем штаны, перелицованные раза три; сапоги, служившие свечными ящиками, один застегнут, другой зашнурован; старый, ржавый меч, взятый из городского арсенала, со сломанной рукояткой и без ножен. Два шнура на платье порваны; лошадь у него хромая, седло старое, подъедено молью, стремена разные; к тому же у лошади сап, спина с изъяном, губы распухли, кожа шелудивая, подбрюшина вздута, все суставы разбухли, неизлечимое воспаление желез, постоянное спотыканье, изъедена она наполовину сломанным недоуздом, а уздечка из бараньей шкуры, от частого натягивания, чтоб лошадь не падала, она разорвалась и теперь связана в нескольких местах; подпруга из шести кусков; нахвостник бархатный с дамского седла с двумя именными буквами, чудно наколоченными из гвоздиков, и связан в разных местах бечевкой (Шекспир, 1937: 67-68; полужирный шрифт мой. - B. M.).

\section{- А. И. Курошева:}

Так вот, Петруччо едет в новой шляпе и в старой куртке; на нем старые штаны, перелицованные раза три; сапоги, служившие свечными ящиками, один на пряжке, другой на шнуровке; старый, ржавый меч, взятый из городского арсенала, со сломанной рукояткой и без наконечника у ножен, с порванными дырочками на портупее. На его хромой кляче - старое, изъеденное молью седло и разные стремена; кроме того, у нее сап, спина с изъяном, губы распухли, кожа шелудивая, подбрюшина вздута, все суставы разбухли, неизлечимое воспаление желез, постоянное спотыкание; она изъедена червями, желта от желтухи, лопатки кривые; взнуздана она наполовину сломанным недоуздком, а уздечка у нее из бараньей шкуры, и от частого натягивания, чтобы лошадь не падала, она разорвалась и теперь связана в нескольких местах; подпруга из шести кусков; нахвостник бархатный с дамского седла с двумя именными буквами, чудно наколоченными из гвоздиков, и связан в разных местах бечевкой (Шекспир, 1950b: 83; полужирный шрифт мой. B. M.).

\section{- П. В. Мелкова:}

Ну как же! Петруччо едет в новой шляпе и старой куртке, в старых, трижды лицованных штанах; сапоги его служили свечными ящиками - один застегнут пряжкой, другой подвязан шнурком; старый ржавый меч из городского арсенала с изломанной рукояткой, отбитым острием и без ножен. На лошади - изъеденное 
молью седло, и стремена друг с другом в родстве не состояли. Вдобавок еще лошадь больна сапом, холка сбита, зубы шатаются, селезенка екает, кожа в болячках, суставы распухли; страдает желтухой и головокружением; ее грызут глисты, спина с изъяном, лопатки торчат, на передние ноги припадает, удила сломаны, а недоуздок из бараньей кожи, да его, видно, так часто натягивали, чтобы лошадь не свалилась, что он разорвался и теперь в нескольких местах связан узлами. Подпруга сшита из шести кусков, а подхвостник бархатный, с дамского седла; на нем именные буквы, красиво выложенные гвоздиками, и связан он бечевкой (Шекспир, 1958b: 240; полужирный шрифт мой. - В. М.).

Эти три фрагмента выглядят скорее как три варианта одного и того же перевода, чем как выполненные разными людьми. Особенно это касается технических деталей упряжи (выделено полужирным в тексте), и даже варианты «нахвостник» и «подхвостник» на деле относятся к одному и тому же ее предмету.

Аналогичные фрагменты, определяемые с помощью опции "Eddy \& Viv", обнаруживаются и в переводах «Бесплодных усилий любви», прежде всего в эвфуистических репликах Армадо и Башки (Костарда, Репки): «Как в простоте душевной человек слушает веления (требования) плоти»; «Великий наместник, представитель (престолоблюститель) тверди (небесной) и единый владыка Наварры, земное божество души моей и плоти (тела) моей (моего) кормитель (питатель) (и покровитель)!»; «...я бы взял в плен свое вожделение и (охотно) отдал бы его какому-нибудь французскому придворному в обмен на новоизобретенную любезность. Я презираю вздохи (вздыхателей) и мог бы, думается, заклясть (устрашить) Купидона». Во всех случаях, если выделить эти фразы в отдельный сегмент текста, показатель их вариативности будет находиться на уровне 0,3-0,4.

Сравнение переводов «Укрощения строптивой» Кузмина, Курошевой и Мелковой показывает один из минимальных зафиксированных на платформе уровней вариативности, отличающихся лишь сотыми долями Eddy (Кузмин — 0,63, Курошева — 0,61, Мелкова — 0,64) (рис. 1). 


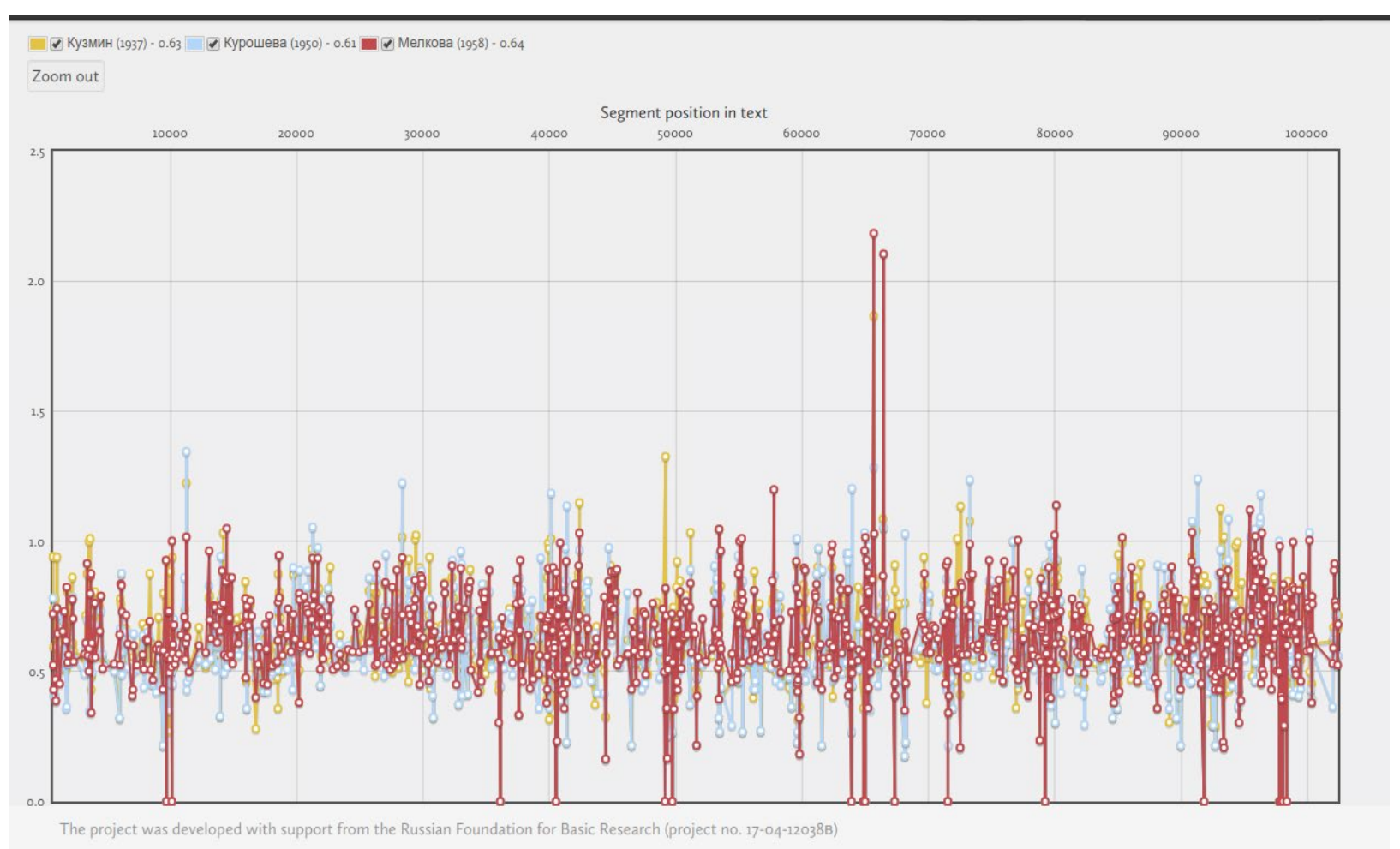

РИС. 1

Манипулируя фильтрами минимальной и максимальной вариативности в меню "Eddy \& Viv", мы можем легко найти десятки подобных примеров, причем лишь половина из них относится к типу «информативных» фрагментов по Т. Чизману, где реплика включает только обращение к герою по имени или краткий ответ «Нет», «Возможно», «Позже» и т. д.

Что же из себя представляют остальные? Анализ работы А. А. Смирнова как редактора с переводчиками лишь предстоит выполнить по данным архивов, но очевидно, что упомянутые выше десятки замечаний включали не только критику «оплошностей» переводчика, но и некие предложенные редактором варианты. В письме Г. Г. Шпету от 15 марта 1934 г. Смирнов называет их «методическими», сравнивая работу с редактором А. Д. Радловой, которая просто принимает «сочиненные мною замены» и М. А. Кузмина, который «разрабатывает предложенные мною “методические" варианты, давая нечто значительно лучшее, что, конечно, меня очень радует» (цит. по: Густав Шпет ..., 2013: 112).

Вероятно, что именно в результате такого сотворчества редактора, настаивавшего на точности (даже в случае метафоры «сало», хотя можно было и подыскать какую-либо форму, омофонную «греку»), в том числе и в деталях упряжи, и поэта-переводчика. Затем эти формы - вероятно, в виде какого-то соглашения, так как неоговоренный перенос вряд ли был возможен перекочевали в более поздние переводы. Таким образом Смирнов, меняя пе- 
реводчиков, мог продолжать работу над совершенствованием перевода одной и той же пьесы. Издание таких текстов под одной обложкой в формате вариорума с соответствующими глоссами могло бы помочь реконструировать общую редакторскую концепцию Смирнова.

Разумеется, определить часть текстуальных совпадений можно было бы и путем простого сравнения текстов переводов, прочитанных один за другим, но платформа VVV позволяет делать это намного более наглядно и - главное - видеть, в каких местах текста они встречаются чаще. По предварительным наблюдениям, в прозе - на первый взгляд более свободной - это происходит примерно в 7-8 раз чаще, чем в стихотворных фрагментах, где при нередком лексическом совпадении синтаксис все же различается.

\section{ГИПОВАРИАТИВНЫЙ ТЕКСТ: ЭКСПЕРИМЕНТ}

В предыдущей работе (Макаров, 2017: 97) я предложил провести эксперимент, создав то, что определяю сейчас как «гиповариативный» текст: механическую комбинацию наименее вариативных переводов каждой реплики (так, как их определяет режим “Eddy \& Viv”).

Предполагалось, что максимальное лексическое совпадение нивелирует особенности стиля переводчика. С учетом формулы вариативности (Cheesman, Flanagan, Thiel, 2012-2013) очевидно, что система будет предпочитать не только тот фрагмент, в котором содержится максимальное количество совпадающих словоформ, но и минимальное количество уникальных, а значит, преимущество имеет самый лаконичный вариант.

В Приложении в конце статьи приведен фрагмент, использованный для тестирования. Так как стихотворные строки заняли бы слишком много места, выбор был сделан в пользу «словесного тенниса» - обмена репликами между Армадо и Мотыльком в «Бесплодных усилиях любви» (II, 1). Из выборки были исключены переводы, сгенерированные с помощью машинных переводчиков от «Яндекса» и Google, а также не учитывались знаки препинания.

Состав гиповариативного перевода по авторам реплик в целом коррелирует с общими показателями вариативности переводов (Eddy). «Лидируют» по количеству фрагментов П. И. Вейнберг и Ю. Б. Корнеев (по 13, показатели Eddy для всего перевода - 0,92 и 0,87 соответственно), далее следуют фрагменты из переводов П. А. Каншина (12; 0,89), М. А. Кузмина $(6 ; 0,84)$, Н. Х. Кетчера (4; 0.89), С. А. Крынского (3; 0,94) и Г. М. Кружкова $(2 ; 0,91)$. В переводе К. И. Чуковского эта сцена отсутствует. Более высокое место Каншина в этом фрагменте, чем по общему показателю Eddy, может быть связано с тем, что его перевод выполнен прозой и ближе стоит к остальным именно в прозаических фрагментах пьесы. Вероятно, стоит уточнить экспе- 
римент - выбрать несколько отрывков из разных пьес, как поэтических, так и прозаических, а также продумать систему подсчета количества упоминаний.

Гиповариативный перевод был показан студентам-филологам ПСТГУ и шекспироведам-участникам круглого стола о проекте VVV на прошедшей в минувшем сентябре конференции «Шекспировские чтения 2018». Они сделали ряд замечаний и предложений, отметив, в частности, что искусственность перевода можно распознать, но лишь в нескольких точках. Замена, например, фрагмента «кресты его не любят» (дословный перевод английской игры слов) или унификация «черствый» и «загрубелый», «меток» и «ловок» создала бы полную иллюзию единого, хотя и не очень качественного перевода.

Интересно, что несколько человек указали, что переводу не хватает именно «живости», имея под ней в виду, очевидно, узнаваемый индивидуальный стиль переводчика, который они отметили в том же фрагменте в версиях Кружкова и (даже!) Каншина.

Тем не менее, эксперимент можно считать удавшимся. Он доказал, что несмотря на почти полуторавековую разницу во времени создания и неоднократную смену переводческих установок, существует некая общая лексическая основа «русского Шекспира», модернизация которой зависит от прорывов в переводческой практике. Так, с увеличением числа современных переводов гиповариативный текст будет модернизироваться, проясняя связи между современными переводами и их предшественниками.

Вероятно, нормальным является и то, что гиповариативный текст слегка архаичен, учитывая, что из всех включенных в анализ переводов три выполнены в XIX в., два - в первой половине или середине XX в. и только два за последние 50 лет. Возможно, полезным было бы составить гиповариативный текст для каждого периода отдельно. Очевидно, что такие слова и обороты, как «отдуть» и «отвалять» у Кетчера и Каншина, «описка ее способностей» у Кетчера и т. д., вполне могут попасть в гиповариативный текст для переводов ХІХ века, но вряд ли - в сводный гиповариативный текст для всего корпуса.

\section{СТРУКТУРА КОРПУСА ПЕРЕВОДОВ: НЕКОТОРЫЕ ВЫВОДЫ ИЗ ПРОЕКТА VVV}

Двухлетний проект применения к текстам на русском языке программного продукта, разработанного для языков с гораздо большей аналитичностью, прежде всего английского и немецкого, подходит к концу. Хотелось бы завершить статью краткими выводами, весьма предварительными, учитывая, что еще не далеко не все корпусы шекспировских пьес полностью отформа- 
тированы, внесены в систему и посегментно связаны с английским оригиналом (представлен в версии Folger Digital Texts).

Анализируя обработанные в том числе и другими участниками проекта материалы, очевидно следующее:

1. Удалось доказательно определить, что система в целом успешно справилась с обработкой кириллических текстов: у авторов разных веков установлены определенные «творческие почерки» (см. ниже анализ кейса Кетчера-Каншина). Также изменения показателя Eddy для переводов в зависимости от того, с чем производится сопоставление, показывает то, что вариативность действительно относительна. В зависимости от выбора переводов для сопоставления важно анализировать динамику (т. е. изменения в ту или иную сторону) этой вариативности. Именно поэтому столь важно внести в систему максимально возможное число переводов, в том числе и малоизвестных или вообще не публиковавшихся: на их авторов, как и на признанных переводчиков, воздействует та же инерция переводческих подходов и стратегий, им так же необходимо бороться с автоматизацией перевода, повторениями находок предшественников. Однако при переходе порога в 7-8 и более переводов, добавление одного или двух новых не дает резких изменений в вариативности и гипервариативности.

2. Если бы существовали «идеальные» языковые условия для переводчиков (прежде всего отсутствие исторических изменений в языке и возможность опираться на весь корпус предыдущих текстов), график вариативности переводов в режиме «История Eddy» представлял бы собой прямую, расстояние которой от горизонтальной оси постоянно бы увеличивалось (т. е. со временем вариативность бы возрастала). Причиной тому было бы стремление переводчиков оттолкнуться от наследия своих предшественников и сознательно делать собственный текст «новым». Однако в реальности такому перепереводу (retranslation, см. подробнеe: Cheesman et al., 2017: 740-741) мешает ряд факторов:

- труднодоступность переводов XIX века и отвержение их на основании эстетических и/или идеологических предпочтений;

- ряд переводчиков (из современных, например, - Г. М. Кружков) в ходе работы сознательно не читают переводы своих предшественников и избегают их прямого влияния на себя. В таком случае речь, правда, может идти о бессознательном усвоении традиции (перевод был прочитан ранее, возможно, услышан в театре или кино, на публичном чтении);

- эстетически особо ценится индивидуальный опыт «общения с Шекспиром», хотя это не мешает переводчикам заимствовать иногда целые фразы друг у друга (ср. выше раздел о «методических» правках А. А. Смирнова); 
- особенно сложная ситуация - у часто читаемых и используемых режиссерами переводов, которые тем самым получают особую влиятельность (фрагменты типа «полцарства за коня», «она его за муки полюбила...»). Переперевод этих фрагментов становится сложным вызовом для переводчиков последующих поколений.

В целом, создаваемый с помощью платформы VVV корпус для индивидуального переводческого сознания - скорее искусственный конструкт, так как ни один переводчик не может руководствоваться или хотя бы знать все тексты, но корпус хорошо передает «воображаемого» «русского Шекспира» как тезаурусный феномен литературы и культуры, который меняется, но в чем-то и остается тем же. Мы видели это на ряде примеров из истории перевода ранних шекспировских комедий.

3. Подтверждено определенное отличие на уровне вариативности и ее изменения между текстами, выполненными в три основные эпохи развития художественного перевода на русский язык. Можно проследить и некоторую стабильность внутри этих групп.

Условно эти группы можно обозначить следующим образом: «группа A» - дореволюционные переводы, особенно выполненные до начала XX ве$\mathrm{ra}^{4}$; «группа В» - переводы, выполненные в 1930-1950-е гг. для двух полных собраний сочинений Шекспира, подготовленных А. А. Смирновым (Шекспир, 1936-1950) и А. А. Смирновым совместно с А. А. Аникстом (Шекспир, 1957-1960); «группа С» — переводы, выполненные в 1990-2000-е гг. В каждом случае между группами могут быть переводы переходного типа, например, подготовленные для издания полного собрания сочинений Шекспира под редакцией Венгерова (Шекспир, 1902-1905) - между группами А и В; или переводы О. П. Сороки — между группами В и С. Эти группы отличаются переводческими установками:

- группа A - малое внимание к технике стиха, упор на передачу смысла без соблюдения при этом эквилинеарности и даже допущение передачи поэтического текста прозаическим;

- группа В - острые дискуссии о наилучшей технике поэтического перевода и оптимального перевода именно шекспировского текста, борьба «буквалистов» и «реалистов»;

- группа С - стилистическое разнообразие и присутствие как «охранительного», так и «ревизионистского» отношения к наследию группы В.

Они также отличаются языковой практикой, ориентируясь на литературный язык своей эпохи.

\footnotetext{
${ }^{4}$ Разумеется, чтобы такое сравнение было возможным, у переводов группы А орфография должна быть приведена к современной.
} 
От чего же в целом зависит вариативность?

Можно пока предложить лишь рабочую гипотезу - от сложного комплекса факторов, в котором надо учитывать: а) количество пьес каждой группы в корпусе - чем больше пьес, тем ниже их вариативность; б) более ранние переводы в целом менее вариативны, при условии, что они были известны и влиятельны, в том числе на сцене (в корпусе ранних комедий краткость сценической жизни не позволяет определить такое влияние, но в подготовленном И. И. Лисович корпусе «Макбета» таковыми, например, являются переводы М. П. Вронченко и А. И. Кронеберга), 3) от индивидуальных стратегий и влияний (поэзия-проза, учитель-ученик).

Разделение общего корпуса переводов на группы и гипотеза о причинах вариативности позволяют определить несколько типов переводов шекспировских пьес:

a) Малый корпус - 5-6 текстов или меньше, неравномерно представленный по группам («Два веронца» - отсутствуют переводы группы C, «Комедия ошибок» - лишь один перевод группы С). В результате - труднопредсказуемая вариативность у групп В и С, низкая вариативность у группы А (рис. 2, 3).

Два веронца - Eddy history

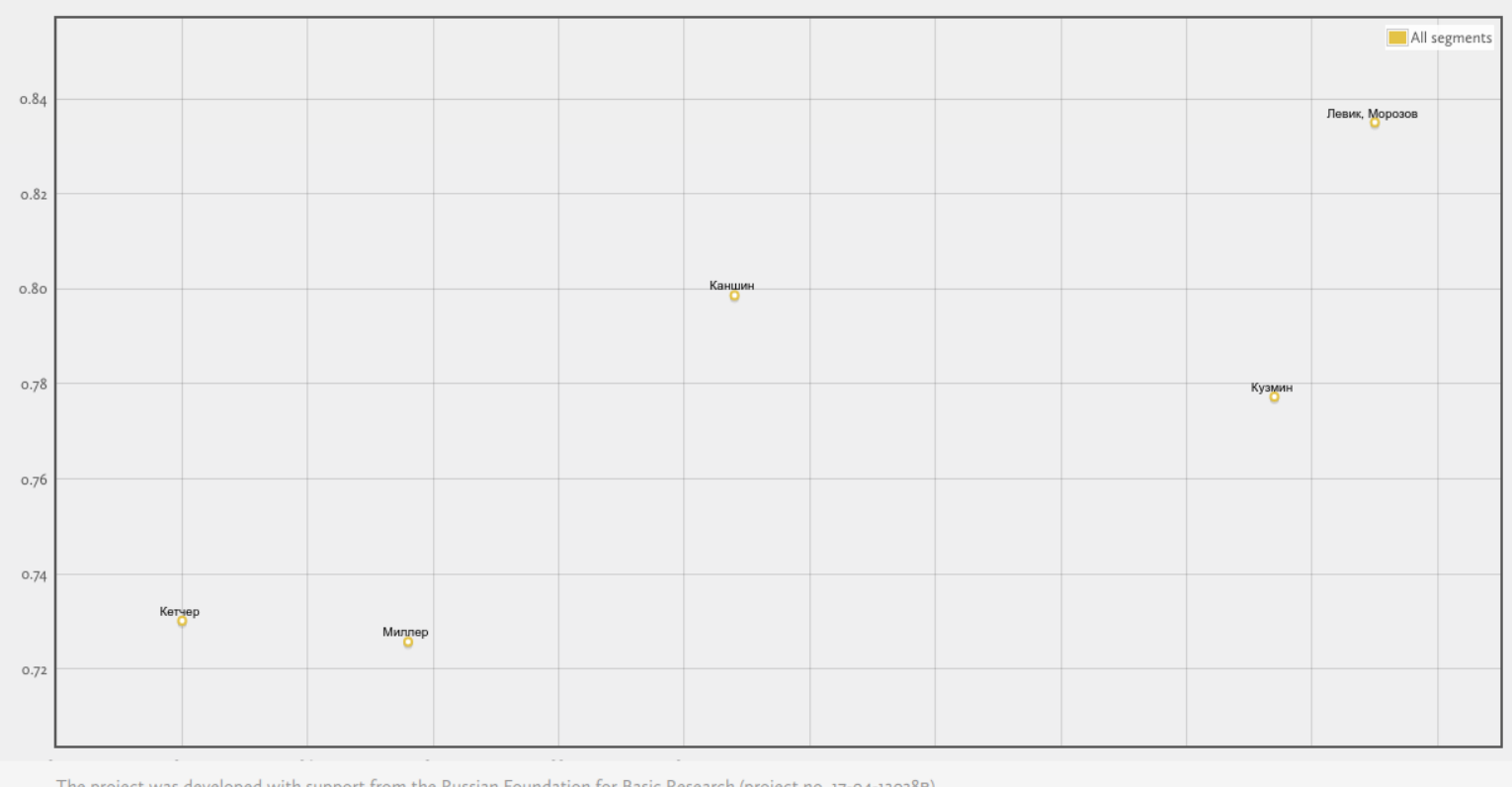

РИС. 2 


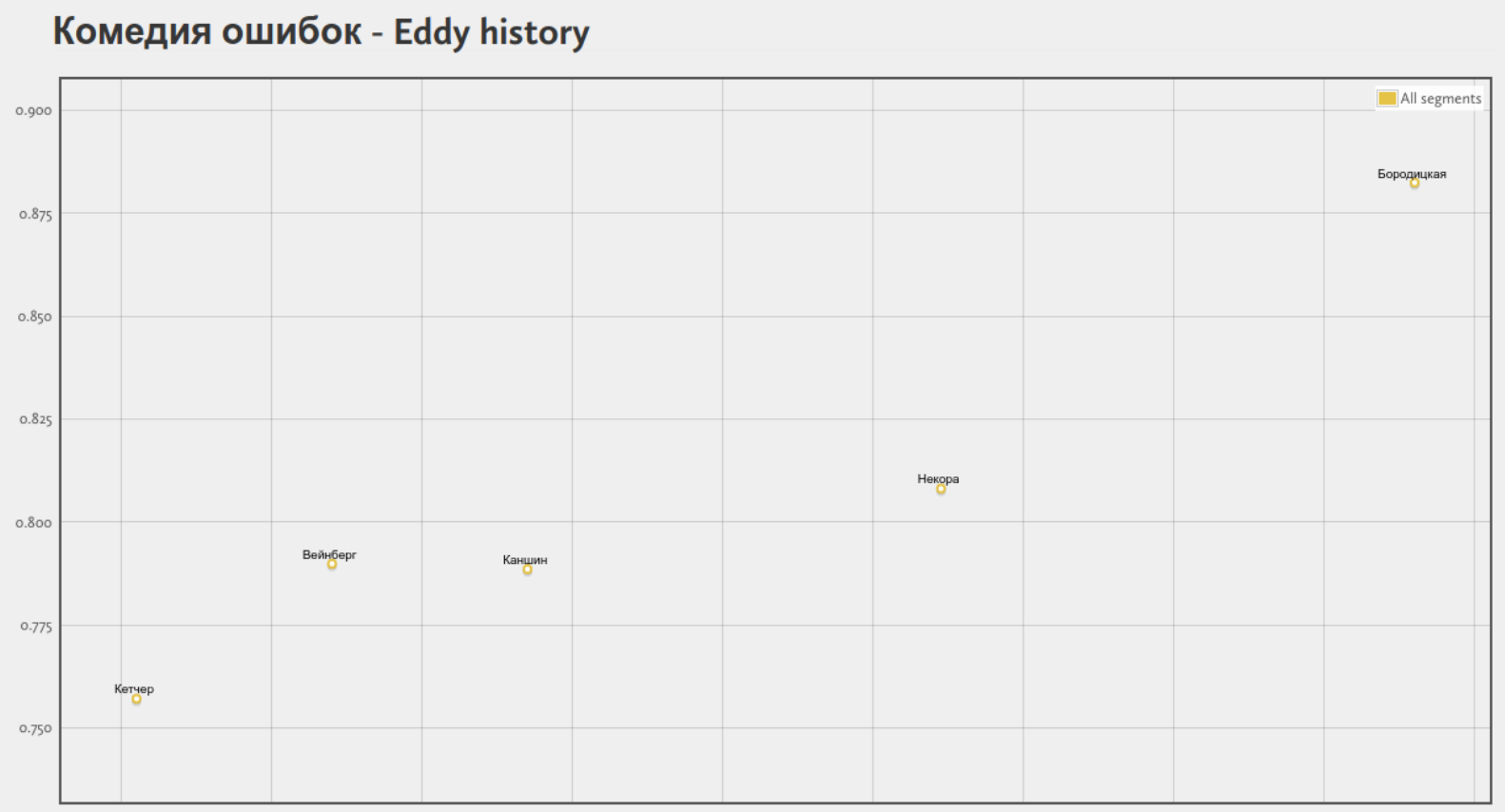

РИС. 3

В обоих случаях переводы группы А банально статистически перевешивают, учитывая то, что в сумме их столько же, сколько переводов группы В и $\mathrm{C}$, и они выполнены примерно с одинаковых переводческих позиций.

б) Большой корпус - более 8-9 переводов, относительно равномерно (не менее 2-3 в каждой) представленный по группам. В результате - низкая и ниже среднего вариативность у групп А и В, в группе C, как правило, «ревизионистские» переводы, пытающиеся создать современный язык для классической пьесы (рис. 4).

Бесплодные усилия любви - Eddy history

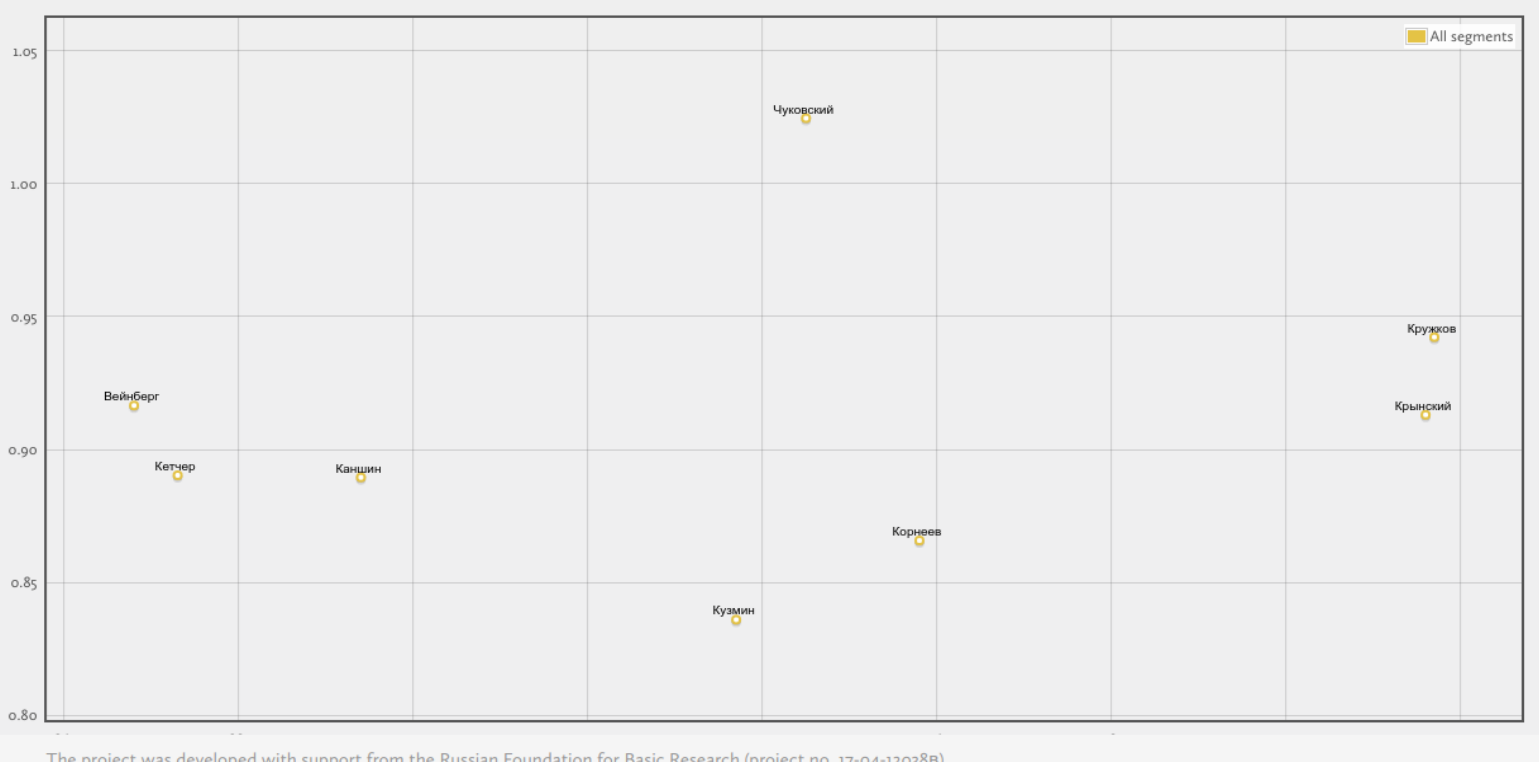

РИС. 4 
Основная масса переводов внутри групп А и В стоит близко друг к другу по вариативности (показателю Eddy), выделяются высокой вариативностью переводы, в которых либо поставлена особая задача (К. И. Чуковский в «Бесплодных усилиях любви» - создать Шекспира, понятного советской комедийной сцене, не слишком усложненного устаревшим юмором), либо крайне много языковых особенностей (например, перевод очень адаптивен к русской языковой культуре).

Примерный вид - плавная кривая распределения, растущая по мере приближения к хронологическому настоящему; возможно, в виде гиперболы или очень растянутой параболы (рис. 5).

Несколько иное распределение - в корпусе «Троила и Крессиды», подготовленном Б. Н. Гайдиным, где в целом переводов почти столько же, но они менее равномерно распределены по периодам: $4-\mathrm{A}, 2-\mathrm{B}$ и $1-\mathrm{C}$. В этих условиях показатели вариативности групп А и В оказываются примерно одинаковыми.

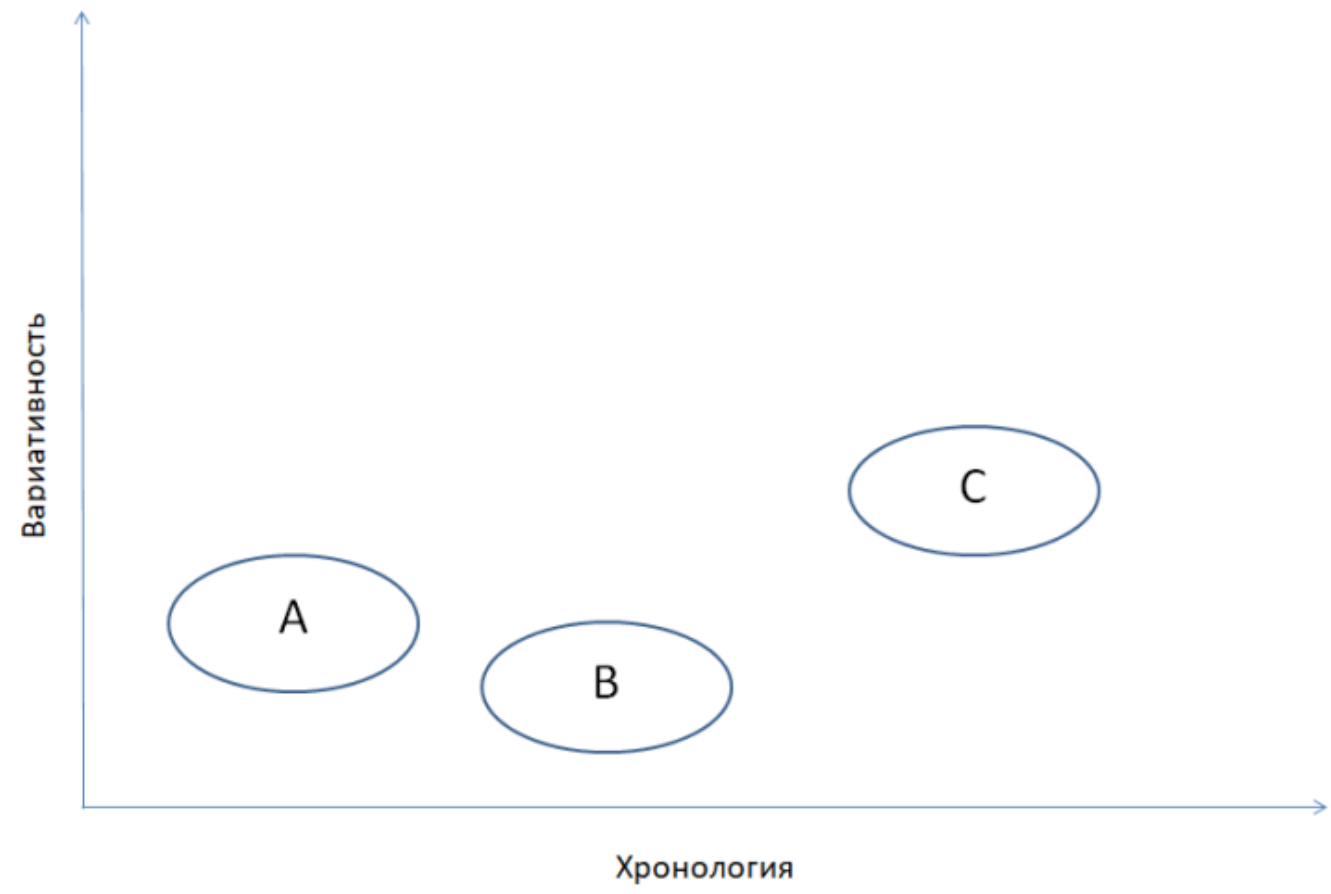

РИС. 5

Напротив, корпусы всех шекспировских «великих трагедий» с их многочисленными, в том числе любительскими и полулюбительскими переводами вполне могут дать «пики вариативности» - т. е. несколько переводов разных эпох, противостоящих как современным им, так и всем последующим. Пока мы нашли только один подобный пример - «Бесплодные усилия любви» К. И. Чуковского, но с расширением корпуса могут найтись и другие. Это «невыбранные пути» переводческого «русского Шекспира», исследовать ко- 
торые особенно интересно, хотя среди них могут попадаться как действительно инновационные, так и просто переводы неудовлетворительного качества (или дефекты форматирования, см. об этом ниже).

Можно с определенной уверенностью сказать, что жанр вряд ли будет оказывать сильное влияние на распределение вариативности внутри корпуса. И сильно стилистически варьирующаяся комедия «Бесплодные усилия любви», и трагедия «Макбет» показывают в целом одну и ту же кривую распределения.

Наконец, можно предположить, что тексты и фрагменты, которые можно отнести к «группе 0» — переводы XVIII — начала XIX в. (С. И. Висковатов, «Юлий Цезарь» Н. М. Карамзина и т. д.), также покажут высокую вариативность - как в силу архаичности языка, так и в силу своей немногочисленности.

Можно с уверенностью утверждать, что низкая вариативность отражает «шекспировский язык» эпохи - некий набор конвенций о переводческих приоритетах и влияние авторитетных переводчиков и редакторов как своеобразных «законодателей мнений», причем не через прямые концептуальные утверждения, а через текстуальную практику.

\section{ДИНАМИКА ВАРИАТИВНОСТИ: БУДУЩЕЕ ПРОЕКТА}

Но наиболее показательным и перспективным, на мой взгляд, является еще один индикатор, связанный с вариативностью, который я хотел бы предложить в данном разделе. Его можно условно назвать «динамикой вариативности» и определять как разность показателей Eddy в том случае, когда сопоставляется полный корпус переводов и некоторые его подразделы, в частности, переводы одной хронологической группы или выбранные по каким-либо другим критериям.

Даже случайная выборка в пределах корпуса для отображения в режиме «История Eddy» дает интерпретируемые интересные результаты, но особенно ценен просмотр по хронологическим группам, к которым мы сейчас и обратимся.

Группа А. Характерна невысокая динамика вариативности - в пределах 0,1-0,25 пункта Eddy. Особенно важно, что динамика одинакова у переводов разных авторов. В трех ранних комедиях переводы Н. Х. Кетчера и П. А. Каншина показывают динамику, различающуюся почти всегда лишь сотыми долями («Бесплодные усилия любви»: общий Eddy — 0,89 и 0,89, Eddy по группе A - 0,74 и 0,75: «Два веронца»: общий Eddy- 0,73 и 0,8, Eddy по группе A - 0,61 и 0,69; «Комедия ошибок»: общий Eddy — 0,76 и 0,79, Eddy 
по группе $\mathrm{A}-0,70$ и 0,69 соответственно). Возможные интерпретации включают влияние Кетчера на Каншина либо то, что оба перевода выполнены целиком прозой. Вектор вариативности всегда направлен вниз, т. е. внутри группы переводы менее вариативны, чем в корпусе в целом (рис. 6).

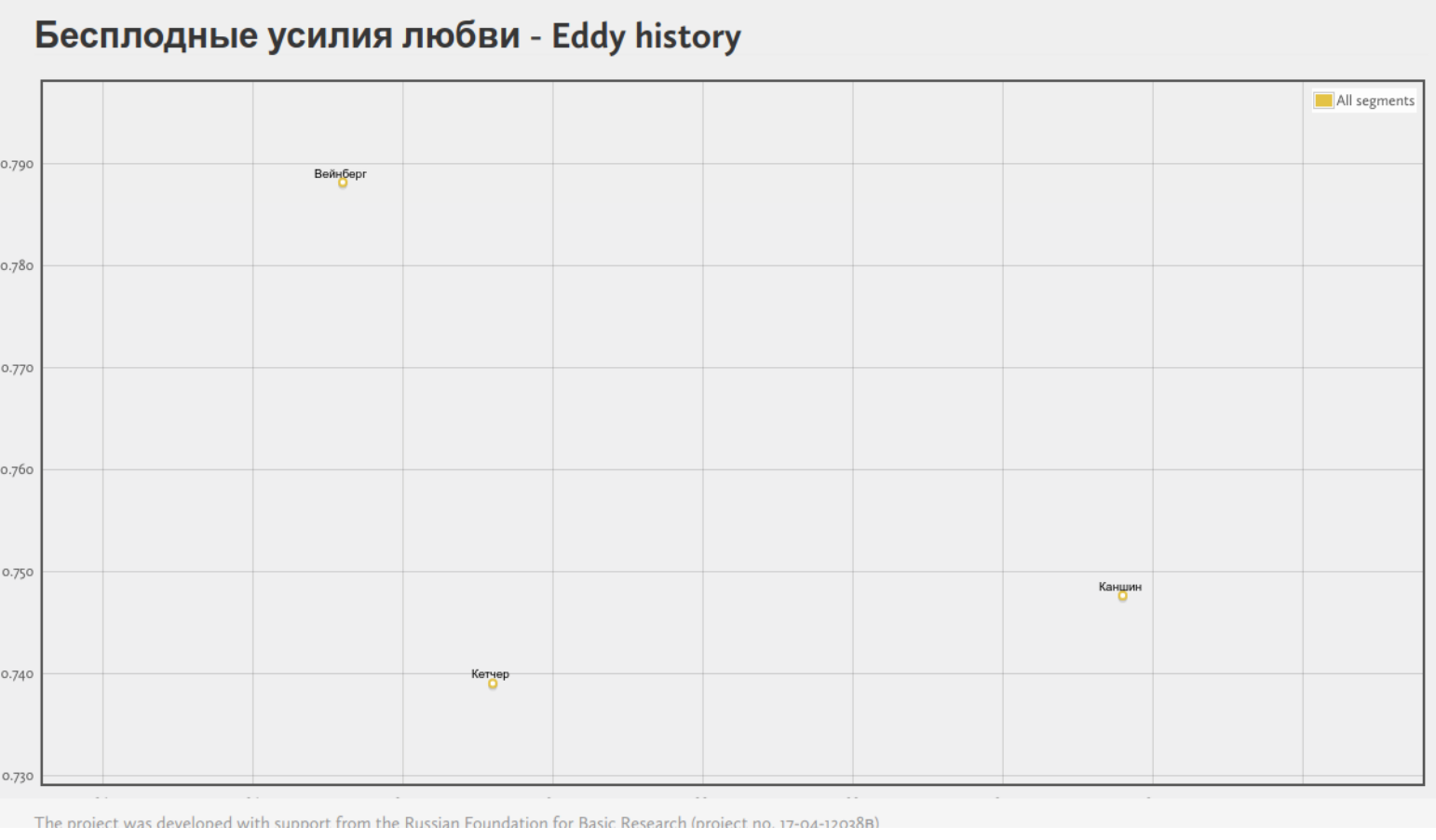

РИС. 6

Группа В. Возможна различная динамика вариативности. Так, в «Двух веронцах» (общий Eddy) переводы $\mathrm{B}$ В. Левика - М. М. Морозова и М. А. Кузмина дают показатель Eddy 0,84 и 0,78 соответственно, а при сопоставлении в рамках группы В вариативность отличается лишь тысячными долями (примерно 0,6147 и 0,6109 соответственно). Так как группа С здесь отсутствует, очевидно, что какая-то часть лексики принципиально более современная в переводе Левика-Морозова, нежели у Кузмина, учитывая более позднюю редактуру первого.

Группа С. Также возможна различная динамика вариативности в связи с большими различиями методологий и переводческих подходов. Низкая динамика вариативности - у переводов, принципиально не опирающихся на работы ни предшественников, ни современников (в «Бесплодных усилиях любви» перевод К. И. Чуковского (группа В) при любых сопоставлениях не дает более $0,06-0,08$ вариативности). Такая низкая динамика связана с «пиками вариативности» (рис. 7). 


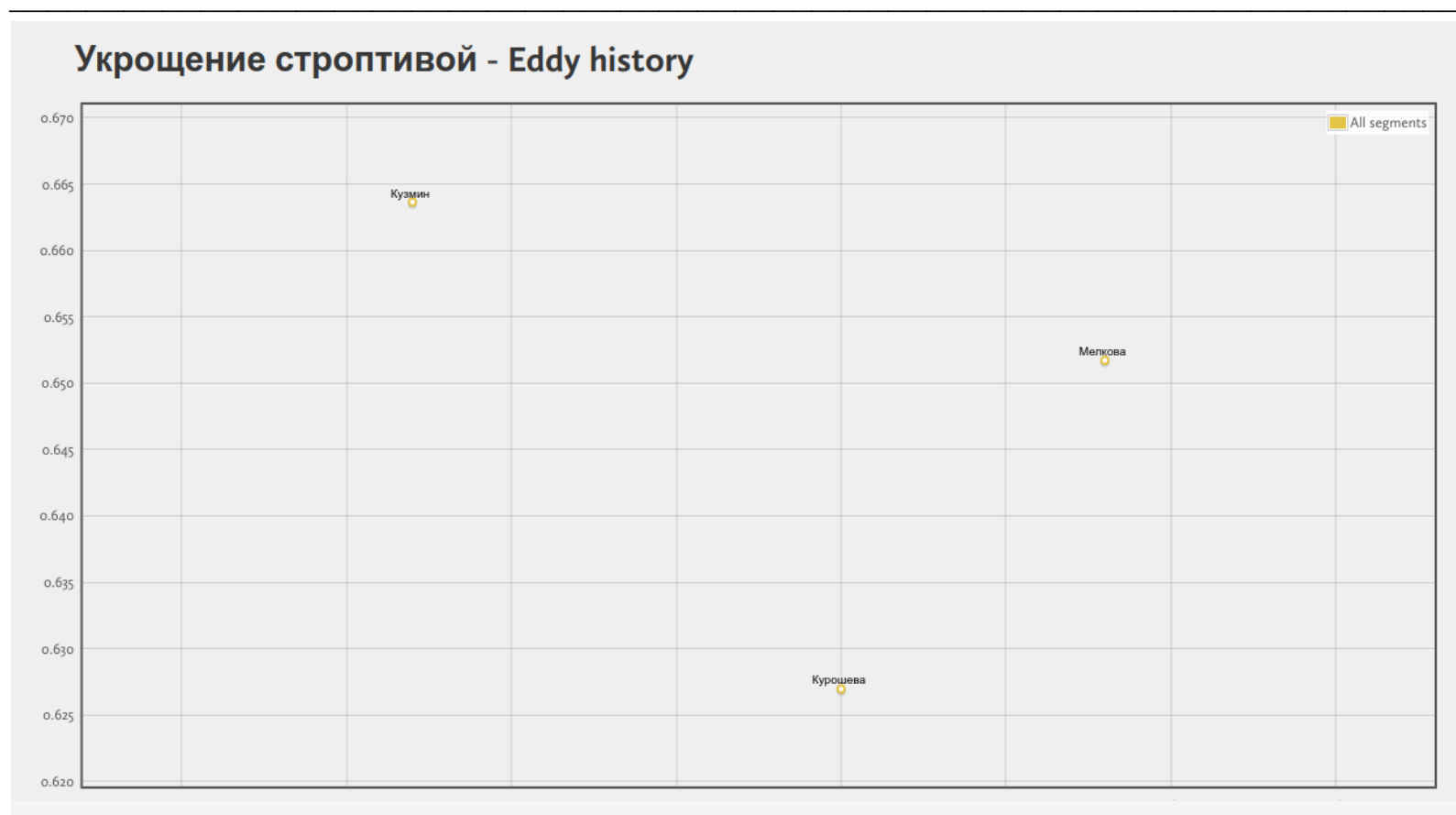

РИС. 7

Интересно, что «ложные пики» - одинаковая вариативность в общей выборке, но резкий рост динамики при сопоставлении друг с другом - может с достаточной точностью указывать на масштабные сбои форматирования. Это произошло, например, в корпусе «Бесплодных усилий любви», где переводы Г. М. Кружкова и С. А. Крынского демонстрировали идентичную вариативность в общей выборке $(0,9)$, а между собой — разницу в 0,7 пункта Eddy. После внесения исправлений картина стала более реалистичной: общая выборка - близкие показатели вариативности 0,94 и 0,91, а при выборке только из группы $\mathrm{C}-0,68$ и 0,66 соответственно. Можно сделать вывод, что современность постепенно формирует новый шекспировский язык даже вне зависимости от качества перевода или индивидуальных стратегий авторов.

\section{ЗАКЛЮЧЕНИЕ}

Со временем, когда появится полный современный перевод всех шекспировских пьес (т. е. группа С разрастется до как минимум 2-3 вариантов для каждой пьесы), вариативность этих текстов будет снижаться, а группы А возрастать по мере устаревания языка. Пока же наименее вариативными будут оставаться переводы группы В, а в случае их небольшого количества группы А и В вместе. Таким образом «шекспировский язык» может быть охарактеризован количественно. Автоматизация подсчетов динамики вариативности в разных сочетаниях переводов поможет определить, какие переводы лексически действительно близки друг другу. 
Однако следует помнить и о культурной инерции российской шекспировской традиции. Чтобы избежать авторских отчислений, режиссеры или прокатчики (особенно это характерно для проекта “Theatre HD”), используют переводы группы А, давая им новую жизнь, или создают коллаж из различных переводов, напоминающий описанный выше гиповариативный текст. Театры и другие культурные институции редко имеют средства, чтобы заказать новый перевод, поэтому, кроме индивидуальной инициативы, основным драйвером шекспировских переводов остаются затратные издательские проекты, которые - особенно если сделаны концептуально - фиксируют «шекспировский язык» своей эпохи или один из его вариантов.

Хотелось бы думать, что анализ динамики вариативности переводов группы В и С ускорит создание новых переводов Шекспира, а значит, и полноценного «шекспировского языка» XXI века.

\title{
ПРИЛОЖЕНИЕ \\ «Бесплодные усилия любви» $(\mathrm{I}, 2)$. \\ Гиповариативный текст \\ (по состоянию на 1 декабря 2018 г., \\ может изменяться при добавлении \\ в соответствующий корпус новых переводов)
}

\begin{abstract}
АРМАДО
Мальчик, в чем выражается меланхолия великого духом человека? (Корнеев)

МОТЫЛЕК
\end{abstract}

Великое то знамение, что опечалится. (Кетчер)

АРМАДО

Разве грусть и меланхолия не одно и то же, маленький бесенок? (Каншин)

МОТЫЛЕК

Нет, нет; о Боже, сэр, нет. (Крынский)

АРМАДО

Чем же ты определишь различие между печалью и меланхолиею, мой нежный юноша? (Вейнберг)

МОТЫЛЕК

В их внутреннем проявлении, загрубелый старец. (Корнеев)

АРМАДО

Почему «старец»? Почему «загрубелый»? (Корнеев)

МОТЫЛЕК

Почему «нежный»? Почему «юноша»? (Корнеев)

АРМАДО 
Я назвал тебя «нежным юношей» потому, что эпитет этот корреспондирует твоим юным годам, которые можно наречь нежными. (Кузмин)

МОТЫЛЕК

А я сказал: черствый старец, находя это соответственным вашему пожилому возрасту, который можно назвать черствым. (Каншин)

АРМАДО

Мило и ловко. (Вейнберг + Каншин)

МОТЫЛЕК

Что вы хотите сказать, сударь? Что я мил, а мои слова метки, или что я меток, а слова мои милы? (Кузмин)

АРМАДО

Ты мил, потому что мал. (Вейнберг + Каншин)

МОТЫЛЕК

Значит, я мало мил, ибо мал. А почему меток? (Корнеев)

АРМАДО

Потому ловок, что изворотлив. (Вейнберг)

МОТЫЛЕК

Вы говорите мне это в похвалу, хозяин. (Каншин)

АРМАДО

В заслуженную похвалу. (Вейнберг)

МОТЫЛЕК

Я бы такой же похвалой и угря похвалил. (Корнеев)

АРМАДО

Как? Разве угорь находчив? (Каншин)

МОТЫЛЕК

Угорь изворотлив. (Корнеев)

АРМАДО

Я говорю, что ты проворен в ответах. Во мне кровь закипает! (Вейнберг)

МОТЫЛЕК

Вот я и получил ответ. (Вейнберг + Корнеев)

АРМАДО

Я не люблю, когда мне перечат. (Кузмин +Корнеев)

МОТЫЛЕК (в сторону)

Он выразился наизнанку: кресты его не любят. (Каниин)

АРМАДО

Я обещал учиться три года с королем. (Вейнберг)

МОТЫЛЕК

Это можно сделать за час. (Кружков)

АРМАДО 
Невозможно! (Кетчер + Каншин + Крынский)

МОТЫЛЕК

Сколько будет трижды один? (Кузмин +Корнеев)

АРМАДО

Я не силен в счете. Это дело буфетчика. (Кузмин + Корнеев)

МОТЫЛЕК

Вы дворянин и игрок. (Кетчер)

АРМАДО

Сознаюсь в том и другом. То и другое завершает лоск порядочного человека. (Каншин)

\section{МОТЫЛЕК}

В таком случае, я уверен, что вы знаете, сколько составляют двойка и туз? (Вейнберг)

АРМАДО

Составляют одним больше, чем два. (Вейнберг)

МОТЫЛЕК

То, что в просторечье называется «три»? (Кузмин + Корнеев)

АРМАДО

Верно. (Вейнберг + Каншин + Корнеев + Кружков + Крынский)

МОТЫЛЕК

Вот видите, как легко учиться! Три вы изучили прежде, чем успели три раза моргнуть глазом; а как не трудно прибавить слово «года» к слову «три» и изучить три года в двух словах - это вам скажет пляшущая лошадь. (Вейнберг)

\section{АРМАДО}

Превосходное вычисление! (Вейнберг + Каншин)

МОТЫЛЕК (в сторону)

Чтоб доказать, что ты нуль. (Кетчер)

\section{СПИСОК ЛИТЕРАТУРЫ}

Густав Шпет и шекспировский круг. Письма, документы, переводы (2013) / отв. ред.-сост., предисл., коммент., археогр. работа и реконструкция Т. Г. Щедрина. М. ; СПб. : Петроглиф. 760 с.

Каганович, Б. А. (2018) Александр Александрович Смирнов. 1883-1962. СПб. : Европейский дом. 240 с.

Макаров, В. С. (2017) «Бесплодные усилия любви» в русских переводах: опыт сравнительного анализа [Электронный ресурс] // Горизонты гуманитарного знания. № 6. С. 85-102. URL: http://journals.mosgu.ru/ggz/article/ view/642 (дата обращения: 01.12.2018). DOI: 10.17805/ggz.2017.6.6

Смирнов, А. А. (2013) О русских переводах Шекспира // Густав Шпет и шекспировский круг. Письма, документы, переводы / отв. ред.-сост., предисл., 
коммент., археогр. работа и реконструкция Т. Г. Щедрина. М. ; СПб. : Петроглиф. 760 с. С. 720-735.

Чизман, Т. (2015) Массивы переводов и их цифровое истолкование // Шекспир в междисциплинарных гуманитарных исследованиях : коллективная монография по материалам Международного научного семинара / ред.-сост. В. С. Макаров, Н. В. Захаров, Б. Н. Гайдин. М. : Изд-во Моск. гуманит. ун-та. 238 c. C. $114-146$.

Чуковский, К. И. (2012) «Бесплодные усилия любви» // Чуковский К. И. Собр. соч. : в 15 т. / предисл. и коммент. Б. Мельгунова и Е. Чуковской. 2-е изд., электронное. М. : Агентство ФТМ, Лтд. Т. 10: Мастерство Некрасова. Статьи 1960-1969. 736 с. С. 627-655.

Шекспир, В. (1902-1905) Полн. собр. соч. : в 5 т. / под ред. С. А. Венгерова. СПб. : Изд. Брокгауз-Ефрон. (Библиотека великих писателей).

Шекспир, В. (1936-1950) Полн. собр. соч. : в 8 т. / под общ. ред. [С. С. Динамова], А. А. Смирнова. М. ; Л. : Academia / Гослитиздат.

Шекспир, В. (1937) Укрощение строптивой / пер. М. А. Кузмина Некоры // Шекспир В. Полн. собр. соч. : в 8 т. / под общ. ред. С. С. Динамова, А. А. Смирнова. М. ; Л. : Academia. Т. 2.646 с. С. 1-129.

Шекспир, В. (1949) Комедия ошибок / пер. Л. С. Некоры // Шекспир В. Полн. собр. соч. : в 8 т. / под общ. ред. А. А. Смирнова. М. ; Л. : Гослитиздат. T. 7.637 с. С. 9-100.

Шекспир, В. (1950а) Избранные произведения. М. ; Л. : Гос. изд-во худож. лит. XVII, 648 с.

Шекспир, В. (1950b) Укрощение строптивой / пер. А. И. Курошевой // Шекспир В. Избранные произведения. М. ; Л. : Гос. изд-во худож. лит. XVII, 648 c. C. $65-100$.

Шекспир, У. (1957-1960) Полн. собр. соч. : в 8 т. / под общ. ред. А. А. Смирнова, А. А. Аникста. М. : Искусство.

Шекспир, У. (1958а) Комедия ошибок / пер. Л. С. Некоры // Шекспир У. Полн. собр. соч. : в 8 т. / под общ. ред. А. А. Смирнова, А. А. Аникста. М. : Искусство. Т. 2. 548 с. С. 103-179.

Шекспир, У. (1958b) Укрощение строптивой / пер. П. В. Мелковой // Шекспир У. Полн. собр. соч. : в 8 т. / под общ. ред. А. А. Смирнова, А. А. Аникста. М. : Искусство. Т. 2. 548 с. С. 181-293.

Шекспир, У. (2012) Отрывки из «Комедии ошибок» (с параллельным английским текстом) в переводе Марины Бородицкой // Иностранная литератуpa. № 10. С. 176-229. URL: http://magazines.russ.ru/inostran/2012/10/s5.html [архивировано в WaybackMachine] (дата обращения: 01.12.2018).

Barber, C. L. (2011) Shakespeare's festive comedy: A study of dramatic form and its relation to social custom. Princeton, NJ : Princeton University Press. x, 265 p.

Cheesman, T. et al. (2017) Multi-retranslation corpora: Visibility, variation, value and virtue / T. Cheesman, K. Flanagan, S. Thiel, J. Rybicki, R. S. Laramee, 
J. Hope, A. Roos // Digital Scholarship in the Humanities. Vol. 32. Issue 4. P. 739760. DOI: $10.1093 / 1 \mathrm{lc} / \mathrm{fqw} 027$

Cheesman, T., Flanagan, K., Thiel, S. (2012-2013) Translation array prototype 1: Project overview [Электронный ресурс] // Version Variation Visualization. URL: http://delightedbeauty.org/vvv/Home/Project [архивировано в WaybackMachine] (дата обращения: 01.12.2018).

Cheesman, T., Roos, A. (2017) Version Variation Visualization (VVV): Case studies on the Hebrew Haggadah in English [Электронный pecypc] // Journal of Data Mining and Digital Humanities. Special issue on computer-aided processing of intertextuality in ancient languages. URL: https://jdmdh.episciences.org/3737/ pdf [архивировано в WaybackMachine] (дата обращения: 01.12.2018).

Magnusson, L. (2001) Language and comedy // The Cambridge companion to Shakespearean comedy / ed. by A. Leggatt. Cambridge : Cambridge University Press. xviii, 237 p. P. 156-178. DOI: 10.1017/CCOL0521770440.010

Smidt, K. (1986) Unconformities in Shakespeare's early comedies. Houndmills, Basingstoke, Hampshire ; L. : Macmillan. xv, 235 p.

Tillyard, E. M. W. (1965) Shakespeare's early comedies. L. : Chatto and Windus. $216 \mathrm{p}$.

Дата поступления: 10.12.2018 2.

Макаров Владимир Сергеевич - кандидат филологических наук, доцент кафедры германской филологии Православного Свято-Тихоновского гуманитарного университета. Адрес: 109651, Россия, г. Москва, ул. Иловайская, д. 9, корп. 2. Тел.: +7 (495) 646-71-38. Эл. адрес: mail@vmakarov.name

Makarov Vladimir Sergeevich, Candidate of Philology, Associate Professor, Department of Germanic Philology, St. Tikhon's Orthodox University. Postal address: Bldg. 2, 9 Ilovaiskaya St., 109651 Moscow, Russian Federation. Tel.: +7 (495) 646-71-38. E-mail: mail@vmakarov.name

\section{Для цитирования:}

Макаров В. С. О вариативности переводов ранних комедий Шекспира: некоторые замечания [Электронный ресурс] // Горизонты гуманитарного знания. 2018. № 6. С. 96-122. URL: http://journals.mosgu.ru/ggz/article/view/923 (дата обращения: дд.мм.гггг). DOI: 10.17805/ggz.2018.6.8 